\title{
Identifying Factors Alleviating Poverty: Experience from Malaysian Zakat Institutions
}

\author{
Mohamed Saladin Abdul Rasool \\ Universiti Teknologi MARA (UiTM), Malaysia \\ Sharifah Adlina Tuan Sayed Amran \\ Universiti Teknologi MARA (UiTM), Malaysia
}

\section{ABSTRACT}

A major challenge for zakat institutions is to identify ways to alleviate poverty. Thus, it is essential to determine factors that influence the incidence of poverty. Determinants of poverty can be used by zakat institutions as a guide by zakat authorities as to draw guidelines and programs to alleviate the poor. The objective of the present paper is to identify the determinants of poverty from the perspective of poor zakat recepients in Selangor, the most populated Muslim state in Malaysia. Using the Had Kifayah method, which is based on maqasid al-shariah principles, the study would outline factors that can be used as a guideline to fight poverty. The present study employed a dataset derived from a survey consisting of 258 head of household heads of low-income group in the state of Selangor, the most populated state in Malaysia. The multiple linear regression (MLR) analysis revealed three factors that influence poverty in this study, namely, unemployment of household heads, non-working household adults and unability to obtain permanent jobs.

Keywords: Poverty, measurements, zakat organizations

\section{INTRODUCTION}

In Islam, poverty is regarded as a disaster, considered undesirable and a serious economic problem. Dogarawa (2003) summarizes poverty as a disaster and a serious problem. Islam advocates that it is essential to seek refuge from it and to fight it. Based on this concept, Islam stresses on a man managing his financial life, and emphasizes on setting up a fair economic system, based on the belief in a man's lawful right to satisfy his natural needs. Muzammil (1995) argues that the conventional definition of poverty from the monetary perspective is unable to capture the attainment of social services, health care, and education. Peerzade (1997) concurred that the Islamic approach as providing provision to enable the poor to enjoy a reasonable standard of living beyond the basic needs of life.

The objective of the present paper is to identify the determinants of poverty from the perspective of poor zakat recipents in Malaysia. Using the had- kifayah (HAK) method, which is based on maqasid alshariah principles to measure poverty, the study would outline factors that can be used as a guideline to fight poverty. This paper is organized as follows. The next section outlines the literature review, whereas the methodology undertaken in this study is deliberated in section 3. Section 4 present 
the findings of the study. Finally, the conclusion of the study is highlighted in section 5 .

\section{LITERATURE REVIEW}

\section{Poverty Measurement}

One of the principles of zakat distribution by some zakat institutions is that the identification of poor is based on hadkifayah (HAK). HAK is the sustainable needs level according to Islamic principles, that is, the amount needed by a household to fulfil their basic needs in accordance with the shariah point of view (Razizi et al., 2017). The term "basic needs" is inclusive of the following six aspects of life: housing, food, clothing, medical, education (both the worldly and spiritually), and transportation. The level of HAK is important so that zakat organizations will be aware of how much zakat assistance and distribution should be given to a family (poverty gap) to fulfil their basic needs and separates between the payer and recipient of zakat (Azman, 2016). In other words, HAK is used to determine whether a household is poor or not (Possumah, 2016). The HAK method was adopted as it was seen as an alternative poverty measurement to the conventional poverty line Income (PLI) method. In general, PLI is the minimum level of income needed by a household to fulfil food and non-food needs (Mansor et al., 2013). In contrast, HAK is a decent standard of living needed by a household to perform daily needs as mentioned by Nurul Afifah et al., (2015) and Sarah et al., (2015). It goes beyond the minimum standard of living of households and is based on time and location as mentioned by Al-Qardhawi (2000), Mansor et al. (2013), and Al-Fanjari (2010).

Malaysian department of Zakat, Waqaf and Hajj (JAWHAR) in the Prime
Minister's Department outlined the main components of the HAK of a household as comprising shelter, food, health, education, and transportation based on maqasid alshariah (objective of the religion) principles. Household needs are calculated according to different category of households. Household members are categorized according to their status and age group, namely, working parents, unemployed adults over 18 years old, children within the 7-17 age group, and children within the 1-6 age group. The total needs of the household are then calculated. If the total income of the household is less than the total needs, then they are considered poor and are eligible for zakat funds. In addition, if there is any situation such as households with a disabled member or households with chronic sickness, the total HAK increases. The HAK determines the level of necessities needed by a household to sustain their daily needs (Mansor et al, 2016). It is calculated based on various variables such as the number of members in a household, the age group of household members, and so on. The HAK in this study is adopted from Lembaga Zakat Selangor (LZS), the highest zakat collector in Malaysia as shown by Table 1 .

The formulation of HAK differs between states in Malaysia as each zakat institution has its own guidelines suited to each state (Azman and Tengku Mansur, 2017). Although the components of the HAK are similar across the states, the figures of kifayah (needs) differ as the cost of goods and services varies from one location to another (Farid, 2010). Household members are categorized according to their status and age group, namely, working parents, unemployed adults over 18 years old, children within the 7-17 age group, and children within the 1-6 age group. From the table, it is obvious that the necessity level of this example is RM 1650, with both, the husband and wife working, an unemployed 
member of family above 18 years old and one school-going child within the 7-17 years old age group and one child within the 1-6 years old age group. Thus, if the total income of the household is less than this calculated figure, then they are considered

Table 1 Had al-Kifayah Determination of a Household by LZS

\begin{tabular}{|c|c|}
\hline Category of Household & $\begin{array}{l}\text { Rate of had al- } \\
\text { kifayah (RM) }\end{array}$ \\
\hline Head of household & 680 \\
\hline Shelter & 260 \\
\hline Food & 140 \\
\hline Clothing & 50 \\
\hline Medicare & 50 \\
\hline Transportation & 180 \\
\hline Working adult & 420 \\
\hline Food & 140 \\
\hline Clothing & 50 \\
\hline Medicare & 50 \\
\hline Transportation & 180 \\
\hline $\begin{array}{l}\text { Child within } 7-17 \text { years old } \\
\text { age group }\end{array}$ & 180 \\
\hline Shelter & 30 \\
\hline Food & 50 \\
\hline Clothing & 50 \\
\hline Medicare & 40 \\
\hline Transportation & 10 \\
\hline $\begin{array}{l}\text { Child within 1-6 years old } \\
\text { age group }\end{array}$ & 130 \\
\hline Food & 30 \\
\hline Clothing & 50 \\
\hline Medicare & 50 \\
\hline TOTAL & 1650 \\
\hline $\begin{array}{l}\text { Additional had al-kifayah } \\
\text { (special case) }\end{array}$ & \\
\hline Disabled & 200 \\
\hline Childcare & 190 \\
\hline $\begin{array}{l}\begin{array}{l}\text { Household with chronic } \\
\text { disease }\end{array} \\
\end{array}$ & 200 \\
\hline TOTAL & 590 \\
\hline
\end{tabular}

Source: Lembaga Zakat Selangor (LZS)

\section{Determinants of Poverty}

In this section, we are interested in ascertaining the factors that have a significant association with the poverty status of a household. Shirazi (1996) explored the role of infaq, an Islamic voluntary tool, where wealth contributes to poor and are eligible for zakat funds. In addition, if there is any situation such as a household with a disabled member or household with chronic sickness, the total HAK or necessities of the household increase.

the public determination of the poverty status of a household in Pakistan. For this objective, he explored the role of infaq, household size, the educational level of the head of the household, the number of earners in the household, and the province the household belongs to in order to evaluate the role of different characteristics that determine the poverty status of a household. His results show that there is a lower probability of poverty for households that live in provinces other than Punjab. As the education level of the head of household increases, the probability of the household being poor decreases. The coefficients of infaq are negative, which means that with the increase of infaq, the probability of a household being poor decreases. Households with 2 or 3 earners or with 4 earners and more have a lower probability to be poor. On the other hand, as the household size increases, the probability of the household being poor increases.

Anand (1977) came up with another method for determining poverty by presenting the poverty determinants in terms of a profile of poverty. It is interesting to note that Shireen (1998) also developed a poverty profile in her study to determine which factors seem to influence poverty. Shireen (1998) estimated various regression equations, each using poverty incidence as the dependant variable. The explanatory variables are the percentage contribution of agriculture to GDP, the labour productivity in the agricultural sector, and the average number of years of schooling. Her results showed that the average number of years of schooling has the strongest relationship with poverty. This suggests that an additional 
year of schooling reduces the incidence of poverty by $8 \%$. Shireen concluded her study by suggesting that poverty is a rural and agricultural phenomenon in the Malaysian scenario.

Tamura (2003) noted that are at least three reasons to pay particular attention to the rural poor. First, they consist of the majority of low-income groups in many developing countries. Second, the geographical characteristics of a location seem to influence the prosperity of its residents. Third, there have been signs of widening inequality within the rural sector. Rupasingha and Goetz (2007) analyzed an expanded set of determinants of poverty, namely, factors related to economic, social, and political influence using spatial data analysis techniques. Social capital, ethnic and income inequality, local political competition, federal grants, a foreign-born population, and spatial effects were found to be important determinants of poverty in the US, along with other conventional factors.

In a study on the determinants of poverty in Mexico by Rodriguez et al. (2010), it was found that the high poverty rates prevalent in Mexico are a reflection of both low income and unequal income distribution. The results of the average intertemporal income of household analysis based on ENNVIH (The Mexican Family Life Survey) dataset give the following findings:

1. Poverty is related positively to household size, the number of illiterate adults in the household, and the location of the household.

2. Poverty is negatively related to the educational level of the household head, household wealth, urban residence in a place with more than 100,000 inhabitants, and the household head being age 60 and older.
A study conducted by Awans and Iqbal (2010) using socioeconomic analysis shows that education, family size, nature of occupation, and public amenities play an important role in poverty alleviation. The incidence of poverty is highest among the daily wage workers and lowest among government employees. The results also show that education, experience and public services are negatively related with the poverty status of individuals. Moreover, the results show that public service availability is also very essential for poverty reduction. It is actually beyond doubt that proper service utilisation symbolizes the improved living standards of people.

Awan et al. (2011, 2012) investigated the relationship between different levels of education and experience on urban poverty in Sargodha, a mediumsized city in Pakistan, using a sample of 330 households. The results revealed that education and experience are negatively related with the poverty status of individuals, which implies that the education of the poor is necessary to break the vicious circle of poverty. Educational attainment and the number of children aged below five were the most significant determinants of poverty in the study conducted by Dartanto and Otsubo (2013) in Indonesia. These two factors are consistently significant in all three types of poverty, namely, absolute, relative and subjective poverty (an extension of multidimensional poverty).

From the discussion above, it has been observed that in order to identify the poverty factors, the concentration of poverty and the high-risk poverty groups, poverty maps, poverty determinants, and poverty profiles can be applied. It appears that some studies have used poverty maps (Ravallion, 1996; Geinneken, 1980), while others preferred poverty determinants (Shirazi, 1996; Shireen, 1998; Rupasingha and Goetz, 2007), and some others have used a poverty 
profile (Anand, 1977; Shireen, 1998). All these terms are similar as they seek to identify the factors that influence poverty so as to enable policy makers to design the most effective policies to address the issue effectively.

Table 2 Determinants of Poverty: Summary of Previous Studies

\begin{tabular}{ll}
\hline \multicolumn{1}{c}{ Factors } & \multicolumn{1}{c}{ Researchers/Authors } \\
\hline Age of household head & Zin (2002); Rodriguez et al. (2010) \\
\hline Household size or dependency ratio & Onn (1989); Shirazi (1996); Zin (2002); World Bank (2002); Harun \\
& (2007); Awan and Iqbal (2010); Rodriguez et al. (2010); \\
\hline Gender & Choudhury (1995); Saidatulakmal and Riaz (2012) \\
\hline Employment type & Amis (1995); Moser (1995); Tamura (2003); Awan and Iqbal (2010) \\
\hline Educational attainment & Shirazi (1996); Amis (1995); Moser (1995); Onn (1989); Johari and \\
& Kiong (1991); Zin (2002); Harun (2006); Awan and Iqbal (2010); \\
& Rodriguez (2010); Awan et al. (2011); Saidatulakmal and Riaz (2012); \\
& Dartanto and Otsubo (2013) \\
\hline Area/location & Aziz (1964); Anand (1983); Johari and Kiong (1991); Ariffin (1997); \\
& Rodriguez (2010) \\
\hline Attitude/culture & Tsakloglou and Papadopoulos (1998); Laderchi (2000); Hanson (2007) \\
\hline Other factors such as access to public & Onn (1989); Johari and Kiong (1991); Shirazi (1996); Amis (1995), \\
services, amenities and health & Moser (1995); Shireen (1998); Tamura (2003); Harun (2006); Rupasingha \\
& and Goetz (2007); Rodriguez (2010) \\
\hline
\end{tabular}

To overcome poverty, policies and programmes should be derived to address the poverty determinants of the present and also the potential poverty determinants of the future (Awan et al., 2012). However, in the present study the notion of poverty determinants is chosen to suit its objectives. In summary, it can be concluded that researchers have identified factors such as the age and gender of the household head, household size, level of education, employment type, location or area of living, attitude, or culture and other factors such as access to public services and amenities as significant variables related to poverty, as shown by Table 2. Identifying these factors are essential as the authorities would be able to address the issue of poverty more effectively as mentioned in the report entitled State of the Nation 2014: Social Mobility and Child Poverty in Great Britain published by Social Mobility and Child Poverty Commission. The commission mentioned that the present young generation have better education level as compared to their parents. However, they are faring worse in terms of employment, earnings, and housing facilities. In other words, determining of these factors are vital for the policy makers to draw appropriate measures to address poverty effectively.

\section{METHODOLOGY}

The monetary poverty measurement adopted in this study is based on the poverty gap approach with $z$ as the poverty gap (HAK Sufficiency ), $z$ ' as the adequacy of income, $y$ as the household income, and $k$ as the poverty line income or the necessities of the household, as explained by:

$$
\begin{aligned}
& z=\{1-(y / k)\} * 100 \% \\
& \text { or } \\
& z^{\prime}=(y / k) * 100 \%
\end{aligned}
$$

The monetary poverty measurement adopted in this study is based on the poverty gap approach, according to the HAK method with $\mathrm{z}$ as the poverty gap. The dependent 
variables, HAK Sufficiency, which represent the HAK method was calculated by computing the difference between the household income and the basic needs outlined by the poverty line and the total necessities of the household, respectively. Alternatively, the concept of adequacy was also introduced to further explain the poverty gap. z'; If z' is equal to or more than $100 \%$, the household is not poor. If $z^{\prime}$ is between $50-99 \%$, then the household is poor as it is unable to fully fulfill its needs. A value of z' being less than $50 \%$ shows that the household is destitute as it is unable to fulfill even half of its needs. Multiple linear regression (MLR) analysis was then used to determine those independent variables that contributed most significantly to the prediction of the dependent. The independent variables included in the analysis were demographic variables, such as age, gender, and marital status of household heads. This is shown by the following diagram.

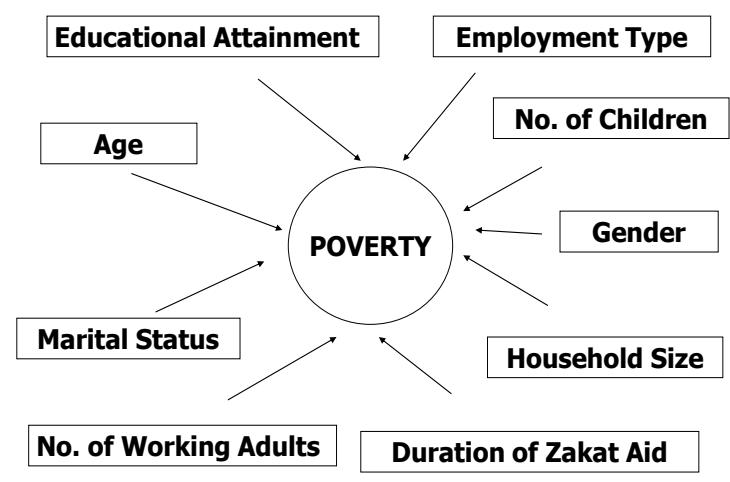

Figure 1 Determinants of Poverty

This quantitative research study consist of employed data derived from a random survey using proportionte random sampling comprising of low-income household heads in Selangor, the most populated state in Malaysia. These household heads were recipients of zakat aid in Selangor. A close-ended questionnaire consisting of three main sections was used as a research instrument to collect data from the respondents identified for this study. Section A obtained information about the head of the household, especially concerning demographic variables; section B consisted of a list of items related to living needs based on maqasid al-shariah principles; section $\mathrm{C}$ was comprised of items pertaining to household income. It is important to note that the items in section B was primarily derived from the expert review sessions whereas items in section $\mathrm{C}$ were adapted from the following sources: (1) Household Expenditure Survey 2009/10 by the Department of Statistics, Malaysia; (2) Household Income/Basic Amenities Survey 2009/10 by the Department of Statistics; (3) Bancian Isi Rumah Miskin Malaysia (Poor Household Census in Malaysia) by the Prime Minister's Department. The expert review sessions were conducted with fourteen scholars with various backgrounds such as Islamic economics, religious studies, and social studies (to reduce biasness).

The dataset of 258 respondents of the study was run through Statistical Package for Social Science (SPSS). Besides 
descriptive statisctics and correlation analysis to present the poverty incidence in the present study, multiple linear regression (MLR) analysis was used to determine the contributions of each of the significant predictors or independent variables toward the variance in the criterion or dependent variable. This study used stepwise regression method to determine those independent variables that contributed most significantly to the prediction of the criterion variable. The independent variables included in the analysis were demographic variables such as age, gender, and narital status of household heads. It is also important to note that variables such as the no of working adults and the duration of receipt of zakat aid are the variables that were lacking in the literature. They consist of continuous and categorial type of data. Dummy variables were created for qualitative or categorical predictors. The MLR was used to explain the variability of the dependent variables. Equation (1) represents the multiple linear regression (MLR) model with twenty one predictors for HAK Sufficiency.

$$
\begin{aligned}
& \mathrm{yi}_{\mathrm{i}}=\beta_{0}+\beta_{1} \mathrm{X}_{1}+\beta_{2} \mathrm{X}_{2}+\beta_{3} \mathrm{X}_{3}+\beta_{4} \mathrm{X}_{4}+ \\
& \beta_{5} \mathrm{X}_{5}+\beta_{6} \mathrm{X}_{6}+\beta_{7} \mathrm{X}_{7}+\beta_{8} \mathrm{X}_{8}+\beta_{9} \mathrm{X}_{9}+ \\
& \beta_{10} \mathrm{X}_{10}+\beta_{11} \mathrm{X}_{11}+\beta_{12} \mathrm{X}_{12}+\beta_{13} \mathrm{X}_{13}+ \\
& \beta_{14} \mathrm{X}_{14}+\beta_{15} \mathrm{X}_{15}+\beta_{16} \mathrm{X}_{16}+\beta_{17} \mathrm{X}_{17}+ \\
& \beta_{18} \mathrm{X}_{18}+\beta_{19} \mathrm{X}_{19}+\beta_{20} \mathrm{X}_{20}+\beta_{21} \mathrm{X}_{21}+\mathbf{\varepsilon i}_{---}
\end{aligned}
$$

where

$\mathrm{y}=$ PLI Sufficiency and IPI

$\mathrm{X}_{1}=$ Age

$\mathrm{X}_{2}=$ Gender

$\mathrm{X}_{3}$-X6 $=$ Marital status

$\mathrm{X}_{7}-\mathrm{X} 11=$ Job status

$\mathrm{X}_{12}-\mathrm{X}_{17}=$ Education level

$\mathrm{X}_{18}=$ Household size

$\mathrm{X}_{19}=$ Duration of aid

$X_{20}=$ Number of children

$\mathrm{X}_{21}=$ Not working adult

$\varepsilon$ is the model error estimated to be normally

distributed with constant variance.

\section{RESULTS \& DISCUSSION}

\section{Descriptive Analysis}

Table 3 shows that almost half of the respondents have income of less than RM1000. However, more than half of the households have the HAK line between RM1000 and RM2000. This explains that more than half of the respondents in the study are poor due to this factor as shown by Table 4. It is also obvious that only a small number of respondents are not poor due to the fact that only a small portion of households $(2.7 \%)$ have income of more than RM3000. Thus, most of the

\begin{tabular}{|c|c|c|}
\hline Range (RM) & INCOME (\%) & HAK (\%) \\
\hline Less than 1000 & 48.4 & 7.0 \\
\hline $1000-2000$ & 38 & 62.8 \\
\hline $2001-3000$ & 10.9 & 26.7 \\
\hline 3001 and above & 2.7 & 3.5 \\
\hline
\end{tabular}
respondents in this study were either poor or destitute as their adequacy levels of income were less than 100 or $50 \%$.

Table 3 Monetary Variable Distribution 
Table 4 Monetary Poverty

\begin{tabular}{|c|c|}
\hline Adequacy Level of Income & HAK (\%) \\
\hline Less than 50\% (Destitute) & 28.3 \\
\hline $50-99 \%$ (Poor) & 59.3 \\
\hline $100 \%$ and above (Not poor) & 12.4 \\
\hline
\end{tabular}

\section{Multiple Linear Regression Analysis (MLR)}

Based on Table 5 and Table 6, the regression analysis results show that the regression model is significant $(\mathrm{F}(3,247)=$ 6.648 , p-value $<0.05)$. The R-square of the model is 0.075 . This indicates that three predictors (unemployed, people with permanent jobs, and non-working adults) can explain about $7.5 \%$ of the variation of HAK Sufficiency. It can be concluded that the HAK Sufficiency is about RM0.479 lower for respondents whose employment status is unemployed compared to other types of employment status, while the other variables are held constant. Other than that, it is RM0.741 higher for respondents who have a permanent job compared to other types of employment status while the other variables are held constant. Besides, HAK Sufficiency increases when the number of non-working adults decreases while the other variables are held constant. However, age, gender (male), marital status (married, bachelor, widow/widower, divorced), household size, duration of aid and number of children failed to meet the selection criteria ( $p$-value $>0.05)$.

Table 5 Summary of Regression Results ANOVA

\begin{tabular}{lccccc}
\hline \multicolumn{1}{c}{ Model 2(b) } & Sum of Squares & df & Mean Square & F & Sig. \\
\hline Regression & 44.832 & 3 & 14.944 & 6.648 & 0.000 \\
Residual & 555.201 & 247 & 2.248 & & \\
Total & 600.034 & 250 & & & \\
\hline
\end{tabular}

Table 6 Summary of Regression Results $R^{2}$

\begin{tabular}{cccccc}
\hline Model & $\mathrm{R}$ & R Square & Adjusted R square & $\begin{array}{c}\text { Standard error } \\
\text { of estimates }\end{array}$ & Durbin-Watson \\
\hline 2(b) & 0.273 & 0.075 & 0.063 & 1.49926 & 1.864 \\
\hline
\end{tabular}

The final estimated model is:

$\hat{Y}=8.418-0.479 *$ unemployed $-0.233 *$ non-working adults $+0.741 *$ permanent job

Based on the model, the determinants of HAK Sufficiency are employment status (self-employed, permanent job, unemployed, pensioner, and part-time/contract), age and non-working adults. It can be concluded that the HAK Sufficiency is about RM0.48 lower for respondents whose employment status is unemployed compared other types of employment status while the other variables are held constant. Other than that, it is RM0.74 higher for those with a permanent job compared to other types of employment status while the other variables are held constant. Besides, HAK Sufficiency increases when the number of non-working adults decreases while the other variables are held constant.

For HAK Sufficiency, permanent job, unemployed and non-working adult are 
significant variables. However, permanent job is positively related while unemployed and non-working adult are negatively related. The coefficient for permanent job is 0.74 , meaning that the poverty gap or HAK Sufficiency of the households whose head has a permanent job is RM0.74 more than those without a permanent job. This is because a household head with a permanent job is expected to have a higher income. In contrast, the HAK Sufficiency for a household with a household head who is unemployed is RM0.48 less than a household where the household head is employed. This could be due to the level of income being less than those who are employed. These findings are similar to studies undertaken by authors, such as Amis (1995), Zin (2002), Tamura (2003) and Awan and Iqbal (2012), who argued that a household with an unemployed household head would be positively correlated with the poverty gap. On the other hand, a household with an employed or a full-time employment household head would be less inclined to be poor. Another variable that is significant is related to HAK Sufficiency is non-working adult. However, the magnitude of the coefficient is only RM0.23, explaining that a household with non-working adult has a poverty gap of RM0.23 less than a household without a non-working adult as the amount of income is relatively smaller.

Scholars have stressed that there are many different factors that influence poverty. However, these factors differ according to countries, location, and area. In this study, issues pertaining to employment are obvious. Thus, the relevant authorities should take into consideration this matter in considering steps to overcome poverty among zakat recipients. It is essential to identify ways to address this subject as it would facilitate the policy makers in addressing poverty from the perspective of policy implications. For instance, unemployment among adult household members is a common reason associated with poverty as revealed by this study. Given the importance of employment for poverty reduction, job-creation should occupy a central place in national poverty reduction strategies. Many employment strategies are often related to agricultural and rural development and include using labour-intensive agricultural technologies, developing small and medium-size enterprises, and promoting micro projects in rural areas.

As a conclusion, productive employment opportunities will have to contribute substantially to achieve the internationally agreed development goals, especially the Millennium Development Goal (MDG). There should be a focus on creating better and more productive jobs, particularly those that can absorb the high concentrations of working poor. Among the necessary elements for creating such jobs are investing in labour-intensive industries, especially agriculture, encouraging a shift in the structure of employment to higher productivity occupations and sectors, and upgrading job quality in the informal economy. In addition, there should also be a focus on providing poor people with the necessary skills and assets that will enable them to take full advantage of any expansion in employment potential. In the case of zakat recipients, these strategies should be formulated to transform them from receiving zakat to paying zakat in the long run.

\section{CONCLUSION}

There are two main issues that are highlighted by this study. Firstly, it is vital for Islamic institutions to devise appropriate poverty measurements such as the HAK method to identify the targeted poverty group. In other words, the proper targeted poor Muslims should be identified through 
an appropriate poverty measurement. This is essential to maintain trust between the society, and these institutions as mentioned by Suhaib (2009) who stresses that ideal Islamic institutions, such as zakat organizations should be able to distribute zakat funds to appropriate recipients, especially the poverty groups Secondly, zakat organizations and other related parties must show efficiency in the Muslim society in various ways such as the ability to reduce the poverty incidence of Muslims and providing efficient services to the potential recipients, and so on. Economists have highlighted the shortcomings in the effort to reduce poverty. For example, many strategies promote self-employment, nonfarm employment in rural areas, targeted employment interventions, microfinance, and credit as means of employment generation, skill formation and training. However, these strategies often address the quantity of employment while the qualitative dimensions, such as equity, security, dignity, and freedom are often absent or minimal.

\section{REFERENCES}

Al-Fanjari, Muhammad Shauqi. (2010). alIslam wa al-Tawazun al-Iqtisadi baina al-Afradwa al-Dual. Jil. 1. Wizarat al-Auqaf. 38-39.

Al-Qardawi, Y. (2000). Fiqh Al Zakat: A Comparative Study of Zakat Regulations and Philosophy In The Light of Quran and Sunnah. New York: King Abdulaziz University Press.

Amis, P. (1995). Making sense of Poverty in IIED. Urban Poverty: Characteristics,Causes and Consequences. Environment and Urbanization, 7(1), 145-157.
Anand, S. (1977). Aspects of Poverty in Malaysia. Review of Income and Wealth, 23(1), 1-16.

Anand, S. (1983). Inequality and Poverty in Malaysia. Oxford: Oxford University Press.

Ariffin, J. (1997). Poverty Amidst Plenty: Research Findings and The Gender Dimension in Malaysia. Kuala Lumpur: Pelanduk Publications.

Awan, M. S., \& Iqbal, N. (2010). Determinants of Urban Poverty: The Case of Medium Sized City in Pakistan. Working Papers \& Research Reports, 2010.

Awan, M. S., Waqas, M., \& Aslam, M. A. (2011). Multidimensional Poverty in Pakistan: Case of Punjab. Journal of Economics and Behavioral Studies, 2(8), 133-144.

Awan, M. S., Waqas, M., \& Aslam, M. A. (2012).Multidimensional

Measurement of Poverty in Pakistan. MPRA Paper No. 41532.

Aziz, U. A. (1964). Poverty and Rural Development in Malaysia. Kajian Ekonomi Malaysia 1(1), 70-105.

Azman, A.R. (2016). "Had Kifayah Zakat di Malaysia: Isu dan Cabaran", dalam Norliana Ismail et.al. Isu Kontemporari Had Kifayah Zakat dan Pengurusan Di Malaysia. Nilai: USIM,1-8

Azman, A.R.; Tengku Mansur, T.Z.A (2017). Strata Had Kifayah Zakat di Malaysia Menurut Maqasid Syariah. Filantrofi: Memperkasa Kewangan Sosial Islam, pp: 179187. Malaysia: USIM Press.

Choudhury, M. A. (1995). The Epistemological Foundations of Islamic Economic, Social, and Scientific Order.

Dartanto, T., \& Otsubo, S. (2013). Measurements and Determinants of Multifaceted Poverty: Absolute, 
Relative, and Subjective Poverty in Indonesia.

Dogarawa, A.B. (2003): "Ethical Issues and Implementation of Islamic Policies for Poverty Eradication", Background Issues to Ethics in Accounting, Proceedings of the 1st National Conference on Ethical Issues in Accounting, Bayero University, Kano.

Farid, S. (2010). Penetapan Had Al-Kifayah di Lembaga Zakat Selangor (LZS). Paper presented at Bengkel Had al-kifayah, $3^{\text {rd }}$ March. Universiti Malaya, Kuala Lumpur

Geinneken, W. V. (1980). Some Methods of Poverty Analysis: An Application to Iranian Data, 1975-1976. World Development, 8, 639-646

Hanson, G. H. (2007). Globalization, Labor Income, and Poverty in Mexico. In Globalization and poverty (pp. 417456). University of Chicago Press.

Harun, M. F. M. (2006). Peminggiran dan Kemiskinan Orang Asli di Negeri Perak. Unpublished doctoral dissertation. UKM, Bangi, Selangor, Malaysia.

Harun, M. F., \& Abdullah, A. F. (2007). Kemiskinan Mengikut Teori Konvensional dan Perspektif Islam. Shah Alam, Selangor: UPENA.

JAWHAR. (2007). Manual Pengurusan Zakat. Putrajaya: Jabatan Wakaf, Zakat dan Haji (JAWHAR), Jabatan Perdana Menteri Malaysia.

Johari, M.Y. and Kiong,C.S.( 1991). "An Overview of Urban Poverty in Sabah", in Johari, M.Y. (ed)., Urban Poverty in Malaysia, Sabah: IDS

Laderchi, C. R. (2000). The Monetary Approach to Poverty: A Survey of Concept and Methods. QEH Paper Series, 58, 1-19.

Lembaga Zakat Selangor (LZS). Annual Report Various Issues. Shah Alam,
Selangor: Lembaga Zakat Selangor (LZS).

Mansor, S., Husna, H., \& Hasan, A. (2016). "Keperluan Terhadap Penentuan Had Al-Kifayah kepada Pembayar Zakat Pendapatan", dalam Norliana Ismail et.al Isu Kontemporari Had Kifayah Zakat dan Pengurusan Di Malaysia. Nilai: USIM, 39-54.

Mansor, S., Hasan, A., Irfan, A., Hisham, I, Noradilah, M. D., \& Saharudin, R. (2013). Had Al-Kifayah di Kalangan Masyarakat Islam: Merungkai Keperluan Kaedah Penentuan Garis Miskin dan Kaya Berasaskan Sunnah Di Malaysia. In: Seminar Antarabangsa Sunnah Nabawiyah (Musnad 2): Realiti dan Cabaran, 3-4 July, Akademi Pengajian Islam, Universiti Malaya

Mohd, S. \& Madiha, R. (2012). Characteristics of Poverty in Pakistan.Developing Country Studies 2.5 (2012): 67-77.

Moser, C. (1995). Women, Gender and Urban Development Policy: Challenges for Current and Future Research. Third World Planning Review, 17(2), 223-243

Muhammad, M. (1995). Abolishing Poverty and Hunger from South Asia. Unpublished paper presented at the Conference on South Asian Integration. Columbia

Nurul Afifah, H., Aisyah, A.R., \& Hairulnizam, W. (2015). "Penentuan Haddul Kifayah Pelajar Institusi Pengajian Tinggi: Kajian Pelajar Siswazah Di Universiti Kebangsaan Malaysia", dalam Nor Aini Ali, Azizi Che Seman \& Mohammad Taqiuddin Mohamad, Isu Kontemporari Agihan Zakat di Malaysia. Kuala Lumpur: Majlis Agama Islam Wilayah Persekutuan dan Jabatan Syariah dan Ekonomi, 
Akademi Pengajian Islam, Universiti Malaya, 79-92

Onn, F. C. (1989). Kemiskinan bandar di Malaysia: Profil dan kedudukan pada 1980an. Ilmu Masyarakat, 15, 43-58.

Peerzade, S. A. (1997). The Definition and Measurement of Poverty: An integrated Islamic approach. The Pakistan Development Review, 36(1), 87-97.

Possumah, T.B. (2016). Had Kifayah Zakah and Adequacy of Income Redistribution. A Proposal Framework. International Journal of Zakat. Vol 1 No.1. November 2016, 36-49.

Ravallion, M. (1996). Issues in measuring and modelling poverty. Economic Research and Training Institute. IDB

Razizi, T. et al. (2017). Item Dan Kadar Penolakan Had Kifayah Zakat Pendapatan di Negeri Sabah: Satu Perbandingan dengan Pelepasan Cukai Pendapatan. Filantrofi: Memperkasa Kewanagan Sosial Islam, pp: 195-202. Malaysia: USIM Press

Rodriguez, J. G., Martinez, M. G., Santoyo, L. S., Lozano, M. Q., \& Weber, G. Y. (2010). Chronic and Transient Poverty in Mexico. Economics Buletin, 30(4), 3188-3200.

Rupasingha, A., \& Goetz, S. J. (2007). Social and Political Forces As Determinants of Poverty: A Spatial Analysis. The Journal of SocioEconomics, 36, 650-671.

Saidatulakmal, O., \& Riaz, M. (2012). Impact of Housing Environment on Poverty, The Journal Economics and Sustainable Development, 3(8): 155-156.

Sarah, A.S., Aisyah, A.R., \& Hairulnizam, W. (2015). "Penentuan Haddul
Kifayah Pelajar Institusi Pengajian Tinggi: Kajian Pelajar Pra Siswazah Di Universiti Kebangsaan Malaysia", dalam Nor Aini Ali, Azizi Che Seman \& Mohammad Taqiuddin Mohamad, Isu Kontemporari Agihan Zakat di Malaysia. Kuala Lumpur: Majlis Agama Islam Wilayah Persekutuan dan Jabatan Syariah dan Ekonomi, Akademi Pengajian Islam, Universiti Malaya, 61-78.

Shirazi, N. S. (1996). Targeting, Coverage and Contribution of Zakat To Households' Income: The Case of Pakistan. Journal of Economic Cooperation among Muslim Countries, 17(3-4), 165-186.

Shireen, M. H. (1998). Income Inequality and Poverty in Malaysia. Landham: Rowman and Littlefield Publishers.

Suhaib, A.Q. (2009). Contribution of Zakat in The Social Development of Pakistan. Pakistan Journal of Social Science, 29(2), 313-334

Tamura, Y. (2003). Redistribution Policies for The Rural Poor of Developing Countries: Towards More Equitable Development. Kuala Lumpur: University Malaya Press.

Tsakloglou, P., \& Papadopoulos, G. (1998). Who Are The Poor in Greece? Analysing Povertyunder Alternative Concepts of Resources and Equivalence Scales. Journal of European Social Policy, 8, 229252.

World Bank (2002). World development report 2001/2002: Attacking poverty. New York. Oxford University Press.

Zin, R. M. (2002). The Asian Financial Crisis and Its Impact on Poverty and Inequality in Malaysia. Institute of Malaysian International 
Studies Working Paper 23. Bangi, Selangor: Institute of Malaysian International Studies (IKMAS), UKM.

Mohamed Saladin Abdul Rasool

Universiti Teknologi MARA (UiTM)

Malaysia

saladin@melaka.uitm.edu.my

Sharifah Adlina Tuan Sayed Amran

Universiti Teknologi MARA (UiTM)

Malaysia 
